\title{
Retraction Note to: Pathogen virulence of Phytophthora infestans: from gene to functional genomics
}

\author{
Suman Sanju • Aditi Thakur • Sundresha Siddappa • \\ Rohini Sreevathsa $\cdot$ Nidhi Srivastava $\cdot$ Pradeep Shukla • \\ B. P. Singh
}

Published online: 9 November 2014

(C) Prof. H.S. Srivastava Foundation for Science and Society 2014

\section{Retraction to: Physiol Mol Biol Plants 19(2):165-177 DOI 10.1007/s12298-012-0157-z}

The authors hereby retract their review article titled "Pathogen virulence of Phytophthora infestans: from gene to functional genomics" (Sanju et al. 2013), previously published in print and online versions of the journal Physiology and Molecular Biology of Plants, due to unattributed use of some text from articles previously published elsewhere without permission (Govers and Gizjen 2006; Huitema et al. 2005; Kamoun 2003; Widmark 2010). This decision was taken to avoid repetition and for the upkeep of professional ethics. All authors sincerely apologize for the inconvenience caused.

The online version of the original article can be found at http://dx.doi.org/ 10.1007/s12298-012-0157-z.

S. Sanju $\cdot$ A. Thakur $\cdot$ S. Siddappa $\cdot$ B. P. Singh

Central potato Research Institute, Shimla, HP, India 171001

\section{N. Srivastava}

Department of Biosciences and Biotechnology, Banasthali

University (Rajasthan), Tonk, India 304022

\section{P. Shukla}

Department of Biological Sciences, School of Basic Sciences,

SHIATS, Naini, Allahabad, India 211007

R. Sreevathsa $(\bowtie)$

National Research Centre for Plant Biotechnology, IARI campus,

Pusa, New Delhi-12, India

e-mail: rohinisreevathsa@rediffmail.com

\section{References}

Govers F, Gizjen M (2006) Phytophthora genomics: the plant destroyers' genome decoded. Mol Plant-Microbe Interact 19(12):1295-1301

Huitema E, Vleeshouwers VGAA, Cakir C, Kamoun S, Govers F (2005) Differences in intensity and specificity of hypersensitive response induction in Nicotiana spp. by INF1, INF2A and INF2B of Phytophthora infestans. Mol Plant-Microbe Interact 18:183-193

Kamoun S (2003) Molecular genetics of pathogenic oomycetes. Eukaryot Cell 2:191-199

Sanju S, Thakur A, Siddappa S, Sreevathsa R, Srivastava N, Shukla P, Singh BP (2013) Pathogen virulence of Phytophthora infestans: from gene to functional genomics. Physiol Mol Biol Plants 19(2): $165-177$

Widmark A-K (2010) The late blight pathogen, phytophthora infestans. interaction with the potato plant and inoculum sources. Doctoral thesis, Swedish University of Agricultural Sciences, Uppsala, Sweden 